\title{
Gender, Trust, and Tax Compliance: The Mediating Effect of Fairness Perception
}

\author{
Yesaya Biely Febrian \\ yesaya.biely@gmail.com \\ Accounting Study Program, Faculty of Business \\ President University, Cikarang, Indonesia \\ Imas Nurani Islami \\ imas.islami@president.ac.id \\ Accounting Study Program, Faculty of Business \\ President University, Cikarang, Indonesia
}

\begin{abstract}
For governments around the world, voluntary tax compliance is critical as they try to minimize budget deficits. In order to boost tax compliance, traditional methods can be expensive to be applied. This study aims to analyze the impact of social factors on the tax compliance intentions of individuals. Supported results were found in a survey of 150 Indonesian taxpayers regarding the effect of social factors on tax compliance. We sum up that gender and trust in government have a significant influence on perception of fairness and perception of fairness on compliance decision. In addition, perception of fairness also succeeded in bridging or mediating gender and trust in government towards compliance decisions. This study might help tax authorities in developing more efficient approaches with less cost to improve taxpayer compliance.
\end{abstract}

Keywords: gender, trust, fairness, tax compliance

\begin{abstract}
Abstrak
Untuk pemerintah di seluruh dunia, kepatuhan pajak sukarela sangat penting dalam rangka meminimalkan defisit anggaran. Untuk meningkatkan kepatuhan pajak, metode tradisional sangat mahal untuk diterapkan. Penelitian ini bertujuan untuk menganalisis dampak faktor sosial terhadap kepatuhan pajak individu. Hasil yang mendukung ditemukan dalam survei terhadap 150 wajib pajak Indonesia mengenai pengaruh faktor sosial terhadap kepatuhan pajak. Kami menyimpulkan bahwa gender dan kepercayaan pada pemerintah memiliki pengaruh yang signifikan terhadap persepsi keadilan dan persepsi keadilan pada keputusan kepatuhan. Selain itu, persepsi keadilan juga berhasil menjembatani atau memediasi gender dan kepercayaan pada pemerintah terhadap keputusan kepatuhan. Studi ini dapat membantu otoritas pajak dalam mengembangkan pendekatan yang lebih efisien dengan biaya yang lebih sedikit untuk meningkatkan kepatuhan wajib pajak.
\end{abstract}

Kata kunci: gender, kepercayaan, keadilan, kepatuhan pajak 


\section{INTRODUCTION}

Indonesia income tax system implements voluntary compliance of taxpayers which relies on general public, academics, tax practitioners, and policymakers (Kemenkeu RI, 2018). Tax always occupies the top position in contributing to state revenue for Indonesia Government (DPR RI, 2019). In 2018, tax revenue contributes IDR 1.136,66 trillion or 79.82 percent that means there is still 20.18 percent losses from the 2018 state budget target (Kemenkeu RI, 2018). A manipulation of financial matters to reduce or even omit paying tax might be tried by some taxpayers (Murphy, 2004). Most tax authorities consider tax compliance as major problem (Guzel et al., 2019). Therefore, the better identification of factors that influence compliance decisions is needed in order to reduce noncompliance and face the enforcement of budgets.

The early study describes tax compliance as fulfillment of taxpayers on their tax responsibility (Guzel et al., 2019). Social factors are found to massively influence compliance decisions of individual (Torgler, 2007). Explaining the response in term of accountability (Sanders et al., 2008) and framing (McCaffrey \& Baron, 2004) becomes the focus in behavioral research in tax compliance. In determining tax compliance, non-economic variables are essential (Muehlbacher et al., 2011). Several factors are covered by tax morale including norms, trust in government, perceptions of fairness, and altruism (Kornhauser, 2007). A complex examination of tax compliance involving norms, trust in government, and perception of fairness believes that those relationships would appear in other countries and give a suggestion to analyze these relationships in non-US countries (Jimenez \& Iyer, 2016).

Trust in government is reflected as simple decision rule whether to support the activities of the state (Hetherington, 2005). The framework of study shows an impact of trust on tax compliance with the direct effect coming from the examination (Gobena \& Van Dijke, 2016). This study investigated indirect effect concerning tax compliance with trust in government through tax fairness perception. An indication of study shows that an essential variable of perception of fairness is trust (Kogler et al., 2013). Another empirical study supports that trust of taxpayers is important for determination of tax compliance (Feld \& Frey, 2002).

Prior study stated that fairness speaks about perception (Reuben \& Winden, 2010). An action influenced by perception of fairness leads to non-compliance (Saad, 2009). A few studies found the tendency of individual taxpayer compliance when there are fairness and justice in country's tax system (Richardson, 2005; Gilligan \& Richardson, 2005). Thus, the level of compliance among taxpayers is influenced by the perception of fairness in tax.

Gender forms all dimensional preferences regarding tax compliance examination that involves fairness, obedience, trust, risk, honesty, and attitudes (Cronson \& Gneezy, 2009). Some studies represent that men are less risk averse than women (Eckel \& Grossman, 2008; Charness \& Gneezy, 2012), although there is no significance of gender difference in the majority of studies (Filippin \& Crosetto, 2016). The perception of fairness relies on expectations and realization involving men and women (Fransson \& Biel, 2000). Based on previous studies, it is reasonable to expect that gender varies the willingness of individual to pay taxes.

In this study, we show the effect of gender and trust on tax compliance through the perception of fairness. The purpose of this study is theoretical model development showing the role of gender and formation of trust before fairness which forming individuals' compliance intentions by interpreting the equality of tax system through the lens of gender and trust. In order to achieve the objectives, the model of taxpayer compliance behavior is developed and tested using three main factors which consist of perception of tax fairness, trust in government, and gender. Focusing on fairness, trust in government and role of gender as tax compliance 
intentions determinants. This study proposes that there is interrelated connection such the perception of tax fairness on the relationships between gender, trust in government and tax compliance decisions in which the perception of fairness fully mediates the influence among them. Providing precious observation on how compliance might be affected by the understanding of the influence of social factors consisting perception of fairness and trust in government on compliance with tax laws.

\section{LITERATURE REVIEW}

\section{Gender}

Gender is social category related to behavior and characteristics of male and female, a perspective of ourselves and others' treatment on us with social category base, and attitudes and feelings regarding characteristics (Anselmi \& Law, 1998). A report from previous research shows lower financially motivated from women than men (Gooderman et al., 2004). The lower motivation from women makes them more accepting even more fair than men. An experiment regarding acceptance decision involving distribution of pie to recipient groups and committees found that men are less likely to accept the proposal than women (Feicht et al., 2017). Men are more overconfident than women, so they are more competitive (Niderle \& Vesterlund, 2007). The honesty of women is higher than men (Bucciol \& Piovesan, 2011). Gender is more directed to role orientation and characteristics, not only biological differentiator, but also relevant to identity and social category. Women are more receptive to justice and more honest than men who are more competitive and confident. Thus, gender could be related to the level of someone's compliance in paying taxes.

\section{Trust in Government}

A psychological state consisting the intentions of vulnerability acceptance based on positive expectations of another intention is defined as trust (Rousseau et al., 1998). In order to pay taxes voluntarily, trust is very essential for taxpayers (Frey \& Torgler, 2007). The decrease of government revenue and performance from taxation results from the increase of lack of trust in government, in addition, the willingness of taxpayers to fulfill their tax obligations would be higher, if there is a high confidence from taxpayers (Torgler, 2003). The positive relationships would be maintained between taxpayers and government (Torgler \& Schneider, 2005).

The taxpayers ' trust in government will seem to have a positive attitude to tax liabilities (Guzel et al., 2019). Perception becomes basis of trustworthiness information for certain targets (Alarcon et al., 2017). The government actions would be supported when there is a trust of individuals, otherwise, they would not accept the actions of the government (Rudolph, 2009). In addition, taxpayers tend to think that the taxes are too burdensome when taxpayers lose their trust in government (Guzel et al., 2019). Consequently, losing trust in government leads taxpayers to evade the taxes (Jimenez \& Iyer, 2016). An economist has intensified a study regarding the high influence of trust in government on tax compliance (Gobena \& Van Dijke, 2016). The increase of taxpayers' behavior towards taxation and commitment to the tax system are resulted from trust in government (Jimenez \& Iyer, 2016). A confirmation of positive relationships that involve trust in government and compliance in many countries has been found (Richardson, The Relationship between Culture and Tax Evasion across Countries, 2008). Hence, the taxpayers would desire pay their taxes obligation when government performs to maintain taxpayers' trust along with the increase of taxpayers' confidence and there must be cooperation between the government trying to create public trust and taxpayers who are willing to pay taxes. 


\section{Perception of Tax Fairness}

Tax fairness perception is a psychological indication in which taxpayers perceive the treatment of authorities is equal to the tax burden they pay (Kirchler et al., 2008). Taxpayers tend to see paying tax as a burden when they pay more than their fair share of tax (Misu, 2011). The identification of fairness perception as one of the factors that influence tax compliance has been found (Saad, 2014). The increase of taxpayers' compliance is resulted from a fair implementation of taxation system by the government whereas the authorities' treatment to taxpayers is equal, responsible, and respectful, it comes to the increase of voluntary tax compliance (Kirchler et al., 2008). Fairness is a perception (Reuben \& Winden, 2010) and the increase of it results in the increase of tax compliance development (Forest \& Sheffrin, 2002). There is a tendency to tax noncompliance action if tax system is unfair and unfavorable for taxpayers (Wenzel \& Thielmann, 2006).

Investigation of the role of tax justice on tax compliance shows that tax fairness and tax compliance have a positive relationship (Casal et al., 2016). A support is shown for the effects of tax fairness perception on tax compliance behaviors (Casal et al., 2016). In addition, a study claims that there is significant relation between perception of tax fairness and tax compliance (Gilligan \& Richardson, 2005). Since taxpayers' compliance be suggested by a fair tax system, taxpayers' perception on tax system is important. In essence, taxpayers be willing to pay taxes if they feel that the tax they are paying provides a fair return for them, otherwise, they tend to take actions that lead to tax avoidance or even evasion.

\section{Tax Compliance Intentions}

Tax compliance is a condition when the declaration of income by taxpayers resulting in the payment of all taxes in order to fulfill tax obligations (Alm, 1991). While other depicts tax compliance as manner accuracy, on time, and in accordance with the law when preparing and reporting tax return or the simplest form of taxpayers' compliance with tax laws (James \& Alley, 2004).

In the literature, there are two approaches that influence tax compliance: Economic Approach (Allingham \& Sandmo, 1972) and Behavioral Approach or Moral Sentiments Theory. The economic approach describes the condition of tax evasion or tax avoidance as a tendency of taxpayers that avoid and evade taxes in which taxpayers are not fulfilling their responsibility on time and in a complete way. Taxpayers compare the tax they pay if the full salary is declared and the penalties if they are detected evade the taxes amid inspections and audits. They would declare income in full, if the tax they pay when declaring full income is less than the amount of paying penalties when they are detected performing tax evasion. On the other hand, they would commit to tax evasion if they found that it could save more money instead of reporting income in full amount. The economic approach suggests that variables in financial quality affect taxpayers' behavior. Besides, behavioral approach exposes noneconomic variables, such as trust in government, perception of tax fairness, and tax morality, which influence tax compliance behavior. Besides the classical expected utility, behavioral factor plays an important role on tax compliance by considering economic variables which consist of tax burden, sanctions, and punishment and non-economic variables including tax morality, attitude, demographic characteristics, perception of fairness, and trust in government (Alm, 1991).

For tax authorities, tax compliance has been becoming the major issue. The level of taxpayers' compliance would rise if there is a harmony between tax office and taxpayers that mutually beneficial (Feld \& Frey, 2007). Convincing taxpayers to fulfill their tax obligations voluntarily found difficult (James \& Alley, 2002). A study proves that tax compliance relies on tax policies and strategies improvement and the increase of taxpayers' motivation (Azmi \& 
Perumal, 2008). In order to ensure the fulfillment of tax timely and detailed commitments, tax authorities should continuously develop tax policy and strategies. In this context, it is hard to determine the need and willingness of taxpayers that would lead to tax compliance (James \& Alley, 2002). The obedience of tax laws resulted by taxpayers' willingness in order to obtain the economic equilibrium of a country (Andreoni, Erard, \& Feinstein, 1998). The complexity of the relationships between perception of fairness and tax behavior leads to the general assumption that perception of fairness positively influences tax compliance (Spicer \& Becker, 1980). Therefore, taxpayer compliance intentions are required in order to support the government, where compliance itself is influenced by many things. Economically, taxpayer compliance is determined by the level of economic savings itself, while non-economically influenced by behavior, trust, perception, and so on.

\section{Hypothesis Development}

\section{The Effects of Trust in Government towards Perception of Fairness}

Trust is formed before social exchange initiation due to entity-based trust in government. In this context, perception of fairness is affected by trust (Holtz, 2013). Trust is found as individual's fairness perception strongest predictor in the literature of management (CohenCharash \& Spector, 2001; Hubbell \& Chory-Assad, 2005). A claim based on counterfactuals literature (Kahneman, 1995) and Folger \& Cropazano (2001) stated that the classification of events is not about inherently fair or unfair, but the interpretation of fair and unfair is based on trustworthiness of the entity. Thus, fairness is subject to individual interpretation as subjective phenomenon. In deciding whether an exchange is fair or unfair, individuals have references to compare the current event. A discussion regarding three counterfactuals: could, would, should (Holtz, 2013). For example, an unfair perception of event if an individual figures that (i) the event could have been managed differently; (ii) the event would have been better if managed differently; (iii) the event should have been managed differently. The interpretation of fairness of an exchange could be either "negative stereotype" or "halo" effect provided by trustworthiness evaluation.

Determination whether an event is fair or not is not inherent, but individuals have a reference to decide. It can be concluded that trust influences the perception of fairness where trustworthiness is the basis of the interpretation of fairness as a subjective event. Thus, according to the trust initiated by Holtz (2013), we hypothesized that:

\section{$H_{1}$ : Trust positively impacts on tax fairness.}

\section{The Effects of Fairness Perception towards Compliance Intentions}

In tax compliance decisions, perception of tax fairness might be essential and significant. The notion about the influence of fairness perception on tax compliance is supported by general theory of tax compliance. A tax compliance theory states that there are three big compliance determinants including perception of fairness (Torgler, 2007). The voluntary compliance decision of tax members appears if there is a fair manner in enacting procedures by the authorities (Saad, 2014).

Tax evasion would occur, if taxpayers perceive that the outputs or the level of public goods are not worth the tax liability, or if the perception of taxpayers leads to the unfair tax schedule (Wenzel, 2004). An indication by a study of taxpayers' perception regarding supportive actions by authorities would lead to the increase of tax compliance (Kirchler et al., 2006). The rationalization of tax evasion would take place, if the tax perception of taxpayers leads to lacks of fairness (Davis, Hecht, \& Perkins, 2003). The perception of taxpayers that there is fairness in the tax system would result in the increase of tax compliance, in addition, tax compliance is also influenced by rewards (Fochmann \& Kroll, 2016). There is significant 
influence of tax fairness, self-interest, and perception of tax fairness on tax compliance behavior (Gberegbe et al., 2015). Jimenez \& Iyer (2016) found supporting evidence that fairness perception mediates the influence of trust in government on compliance intentions.

The intention of tax compliance concerns the perception of fairness of taxpayers, so that if taxpayers consider the tax paid is proportional to the results received, in this context fair, then they want to pay taxes, if not, they try to avoid it. This leads to the following hypothesis:

\section{$\mathrm{H}_{2}$ : Tax fairness positively impacts on tax compliance intentions.}

\section{The Effects of Trust in Government on Compliance Intentions through Perception of Fairness}

A psychological state consisting the intentions of vulnerability acceptance based on positive expectations of another intentions is defined as trust (Rousseau et al., 1998). The definition emphasizes two essential concepts. First, acceptance of risk is required by trust in which trust is unnecessary if there is no exchange risk. Second, in future interactions, they implicitly expect a trustworthy manner by the exchange partner.

As a consequence of trust, there is fairness, it has been explored in the dominant research paradigm that links trust and fairness, and thirty two of thirty six studies noted conceptualizes the outcome of trust, which is fairness. (Holtz, 2013). A slow development of trust based on a series of favorable or fairness interactions with other persons has been stated by the understanding of trust-fairness relationship (Holtz, 2013). A conclusion from research within organization has found that greater trust in partner is resulted to the fair transactions occurred. The trust amount of willingness to place in the organization has a connection with the perception of employees regarding future procedural fairness of organization (DeConinck, 2010). According to management literature, the strongest forecaster of individual's trust in the organization is proven as fairness (Hubbell \& Chory-Assad, 2005).

In this case, the trust and perception of fairness has a close relationship one to another, in which the perception of fairness arises as a consequence of the trust and perception of fairness has an impact on the intentions of tax compliance. This discussion suggests the following hypothesis:

\section{$H_{3}:$ Tax fairness mediates the affection of trust in government on tax compliance intentions.}

\section{The Effect of Gender on Compliance Intentions through Perception of Fairness}

The comparison standards might be the reason of gender differences in expectations and perceptions or judgement, for instance upward and downward comparison, same-sex comparison (Schneck, 2013). Some explains that the overestimation of performance and overconfidence of self-evaluations of men might lead to lower perception of fairness due to elevated entitlement (Niderle \& Vesterlund, 2007). A proof has been showed that the obedience level to authority of women is higher than men resulting in the more compliance of women than men (Cadsby et al., 2006).

Men and women have different comparative standards in perceptions of views, where men tend to be more confident which results in lower perceptions of fairness than women, in addition men have lower levels of compliance to the authority than women which can be linked to the intentions of tax compliance. Thus, we propose following hypothesis:

\section{$\mathrm{H}_{4}:$ Gender positively impacts on tax fairness.}

\section{$H_{5}:$ Tax fairness mediates the affection of gender on tax compliance intentions.}




\section{RESEARCH METHOD}

The information regarding identification of taxpayers, trust in government, perception of fairness, and compliance intentions was collected using survey. Different sources of participants in Jabodetabek area were collected as social perception determination of various taxpayers. The collection of data was conducted from October 8, 2019 to October 29, 2019. The random sampling is used as a method to obtain the respondent. We apply Hair et al. (2010) Model which specifies the numbers of respondent $n$ (numbers of question) $x$, this research involved 12 questions which resulting in a minimum number of participants of 60 . The gender used in this study is male and female. The adoption from Kogler et al. (2013), Nakayachi \& Cvetkovich (2010), Herda \& Lavelle (2011), Blanthorne \& Kaplan (2008), and Kogler et al. (2013) were used in the questionnaire.

The survey had 175 initial participants, but the failure of completing questions and meeting the requirement resulted in the removal of 25 responses from data analysis. The usable responses for data analysis were coming from 150 participants. The use of Structural Equation Model (SEM) is suitable for the testing and analysis of the relationship model due to ability to test relationship for various variables and its effectiveness in absorbing the effect of latent on dependent variables (Jimenez \& Iyer, 2016). Since the hypothesis proposed involves the factors that influence taxpayers' compliance sequentially, the measurement is focused on a single model. In running the data, PLS was used to perform Structural Equation Model (SEM). The use of Structural Equation Model (SEM) is suitable for the testing and analysis of the relationship model due to ability to test relationship for various variables and its effectiveness in absorbing the effect of latent on dependent variables (Jimenez \& Iyer, 2016). The demographic information is depicted in Table 1.

Table 1. Demographic Information

\begin{tabular}{|c|c|}
\hline Indicator & Percentage \\
\hline \multicolumn{2}{|l|}{ Gender } \\
\hline Male & $17.3 \%$ \\
\hline Female & $82.7 \%$ \\
\hline \multicolumn{2}{|l|}{ Age } \\
\hline $18-24$ & $67.3 \%$ \\
\hline $25-34$ & $14.0 \%$ \\
\hline $35-44$ & $10.0 \%$ \\
\hline $45-54$ & $5.3 \%$ \\
\hline $55-64$ & $3.3 \%$ \\
\hline \multicolumn{2}{|l|}{ Occupation } \\
\hline Student & $53.3 \%$ \\
\hline Employee & $30.0 \%$ \\
\hline Entrepreneur & $8.0 \%$ \\
\hline Civil Servant & $2.7 \%$ \\
\hline Other & $6.0 \%$ \\
\hline
\end{tabular}

\section{RESULTS AND DISCUSSION}

Data Demographic

The mean, standard deviations, correlation of variables, and Cronbach's alpha (in bold diagonal) are described in Table 2. The mean value of gender represents a value of 4.31 which refers to the dominating participants by female. So, we can clearly see the differences in 
behavior that is being studied between those genders. The variables of trust, fairness, and compliance have mean value slightly above the midpoint of the scale or 2.5 which indicate that the average taxpayer has a good level of trust, fairness perception, and tax compliance. In Table 2, gender has positive correlation with fairness $(\mathrm{r}=0.483, \mathrm{p}<0.01)$ indicating that the increase in fairness is in line with the positive values of gender that refer to female. Trust and fairness are also positively correlated with each other $(\mathrm{r}=0.373, \mathrm{p}<0.01)$. In addition, taxpayers' perception of fairness leads to positive correlation with compliance intentions $(r=$ $0.692, \mathrm{p}<0.01)$.

Table 2. Mean, Standard Deviation, Variable Correlation, and Alpha

\begin{tabular}{|c|c|c|c|c|c|}
\hline$\overline{\mathrm{X}}$ & $\sigma$ & $\mathrm{G}$ & $\mathrm{T}$ & $\mathrm{F}$ & $\mathrm{C}$ \\
\hline 4.3 & 1.52 & 1.000 & & & \\
\hline 1 & & & & & \\
\hline $8^{3.4}$ & 0.97 & & 0.898 & & \\
\hline $2^{3.8}$ & 1.06 & $\begin{array}{l} \\
*\end{array}$ & $\begin{array}{r}0.373 \\
*\end{array}$ & 0.86 & \\
\hline $4^{3.6}$ & 1.06 & & & 0.692 & 0.817 \\
\hline
\end{tabular}

*Sig at $\mathrm{p}<0.01$

\section{Measurement Model Analysis}

The initial measurement was started by validity and reliability test. In accordance with Hair et al. (2013), the researcher ensured that loading value of each indicator is greater than 0.70 with $<0.01 \mathrm{p}$-value significance, and all the loadings passed the criteria as represented in Table 3. The AVEs (Average Variant Extracted) of gender, trust, fairness and compliance in sequence are $1.000,0.765,0.710$, and 0.732 which exceed the standard limit of 0.5 for good models. The details of convergent validity could be shown in Table 3.

Table 3. Convergent Validity and Reliability Test

\begin{tabular}{|c|c|}
\hline Items & Loading* \\
\hline \multicolumn{2}{|c|}{ Gender $(\mathrm{AVE}=1.000 ; \mathrm{CR}=1.000)$} \\
\hline Male or female & 1.000 \\
\hline \multicolumn{2}{|c|}{ Trust $(\mathrm{AVE}=0.765 ; \mathrm{CR}=0.929)$} \\
\hline Indicator 1 & 0.869 \\
\hline Indicator 2 & 0.874 \\
\hline Indicator 3 & 0.895 \\
\hline Indicator 4 & 0.861 \\
\hline \multicolumn{2}{|c|}{ Fairness $(\mathrm{AVE}=0.710 ; \mathrm{CR}=0.907)$} \\
\hline Indicator 1 & 0.824 \\
\hline Indicator 2 & 0.876 \\
\hline Indicator 3 & 0.802 \\
\hline Indicator 4 & 0.866 \\
\hline \multicolumn{2}{|c|}{ Compliance $(\mathrm{AVE}=0.732 ; \mathrm{CR}=0.891$} \\
\hline Indicator 1 & 0.851 \\
\hline Indicator 2 & 0.871 \\
\hline Indicator 3 & 0.844 \\
\hline
\end{tabular}

*Sig at $\mathrm{p}<0.01$

After that, the reliability assessment was done in order to measure the model consistency on the concept. The standards of composite reliability and Cronbach's alpha must be fulfilled 
above 0.70 (Chong \& Monroe, 2013) and all the variables met the standards with the composite reliability range of 0.891 to 1.000 (Table 3 ) and Cronbach's alpha range of 0.817 to 1.000 (Table 2).

Table 4. Discriminant Validity

\begin{tabular}{ccccc}
\hline & $\mathbf{G}$ & $\mathbf{T}$ & $\mathbf{F}$ & $\mathbf{C}$ \\
\hline $\mathbf{G}$ & $\mathbf{( 1 . 0 0 0 )}$ & & & \\
$\mathbf{T}$ & $0.683^{*}$ & $\mathbf{( 0 . 8 7 5 )}$ & & \\
$\mathbf{F}$ & $0.737^{*}$ & $0.703^{*}$ & $\mathbf{( 0 . 8 4 3 )}$ & \\
$\mathbf{C}$ & $0.722^{*}$ & $0.627^{*}$ & $0.692^{*}$ & $\mathbf{( 0 . 8 5 5 )}$ \\
\hline
\end{tabular}

$*$ Sig at $\mathrm{p}<0.01$

The comparison of square roots of AVE and construct correlations was performed in order to determine discriminant validity and presented in Table 4 . The valid consideration is taken if the square rooted AVEs of construct is exceeding the value of correlation between pairs of construct (Hair et al., 2013). Table 4 depicts that all the diagonal elements (AVE) are exceeding the correlation in the same column, it means that discriminant validity test is passed. Over all, the measurement analysis indicates that the model is reliable and valid.

\section{Structural Model Analysis}

After the items passed reliability and validity construct in analysis of measurement model, it continues to execute the structural model analysis (Chong \& Monroe, 2013). According to data processing performed, the goodness of fit is obtained by Q-square value in which the higher the Q-square, the better the model or more fit the data. It shows compliance R-square of 0.478 and 0.618 fairness R-square which mean the percentage of compliance and fairness could be explained by $48 \%$ and $62 \%$. Besides, the Q-square is derived from the formula: $1-\left[\left(1-R^{2}{ }_{1}\right) \times\left(1-R_{2}{ }_{2}\right)\right]=1-[(1-0.618) \times(1-0.478)]=0.801$

The Q-square explains the data diversity could be described by the model is $80 \%$, while the remaining be described by other factors outside the research model.

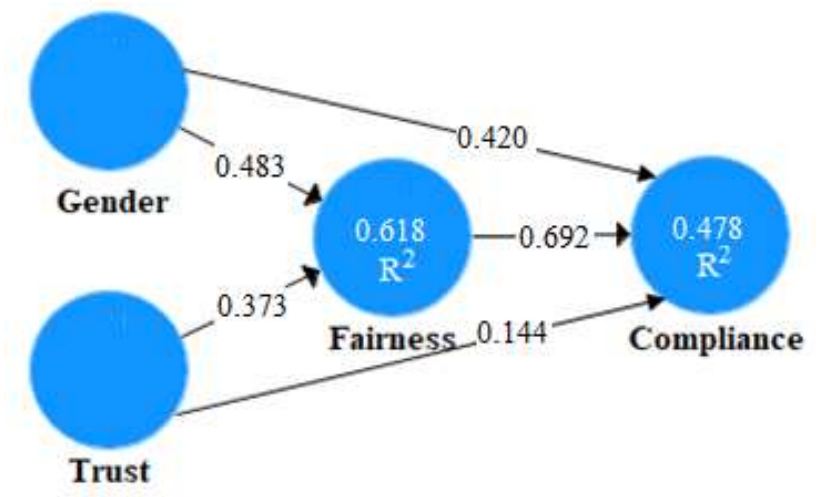

Figure 1. PLS Model and Result

Table 5. Indirect, Direct, and Total Effect

\begin{tabular}{ccc}
\hline Indirect effect (G-F-C) & $0.483 \times 0.692$ & 0.334 \\
\hline Direct effect & & 0.420 \\
& & \\
Total effect & & 0.754 \\
VAF (G-F-C) & $0.334 / 0.754$ & 0.443 \\
\hline
\end{tabular}




\begin{tabular}{lcc}
\hline Indirect effect (T-F-C) & $0.373 \times 0.692$ & 0.258 \\
Direct effect & & $\underline{0.144}$ \\
Total effect & & 0.402 \\
VAF (T-F-C) & $0.258 / 0.402$ & 0.642 \\
\hline
\end{tabular}

Table 6. Direct effect of $\mathrm{T}$ to $\mathrm{F}$

\begin{tabular}{cc}
\hline Path Coefficient & P-value \\
\hline 0.373 & 0.01 \\
\hline
\end{tabular}

Table 7. Direct effect of F to TC

\begin{tabular}{cc}
\hline Path Coefficient & P-value \\
\hline 0.692 & 0.01 \\
\hline
\end{tabular}

Table 8. Direct effect of G to F

\begin{tabular}{cc}
\hline Path Coefficient & P-value \\
\hline 0.483 & 0.01 \\
\hline
\end{tabular}

The correlation between trust in government and perception of fairness is reflected in the PLS result in which they are significantly correlated with 0.373 path coefficient at $p<0.01$. It leads hypothesis 1 to be supported. Tax compliance intentions is shown positively influenced by fairness perception (path coefficient $=0.692, \mathrm{p}<0.01$ ) which causes the support of hypothesis 2 significantly. The effect of gender on perception of fairness in hypothesis 4 is also supported by the results of 0.483 path coefficient at $\mathrm{p}<0.01$.

Investigation of fairness perception as mediating variable is performed in further analysis. VAF (Variance Accounted For) is adopted in this study to measure mediation relationship. VAF is interpreted as "no mediating effect" (value $<20 \%$ ), "partial mediating effect" (value $20 \%-80 \%$ ), and "fully mediate" (value $>80 \%$ ) (Hair et al., 2013). Table 5 clearly depicts that VAF value of trust-fairness-compliance is 0.642 or $64.2 \%$ which means fairness perception partially mediates trust in government and compliance intentions. VAF value of 0.443 or $44.3 \%$ belongs to gender-fairness-compliance relationship which demonstrates partial mediating effect of fairness perception among them. Although mediating partially, but still, those results lead to the conclusions that support hypothesis 3 and 5.

\section{Discussions}

This study has proposal and examination of taxpayers' perception of fairness as mediating variable of the influence of gender on tax compliance intentions in Indonesia. An investigation of the correlation between trust in government and tax compliance intentions is also performed through the role of taxpayers' perception of fairness. The analysis represents that both gender and trust in government give impact to the mediator and found to be essential predictors.

Gender is found a positive relationship which indicates that perceptions of fairness is influenced by the existence of gender role. By this finding, a consistency is found in line with some research by Gooderman et al. (2004), Niderle \& Vesterlund (2007), and Feicht et al. (2017). They report that female is less motivated, less overestimate, less overconfident, and more likely to accept the proposal than male that lead to make female more accepting and higher perception of fairness compared to male. In addition, trust also has a positive impact on the perception of justice in their relationship. This supports the findings of Kogler et al. (2013) who said that trust is an essential variable in determining perception of fairness and Holtz (2013) who proved that trust becomes the basis of interpretation of fairness as subjective event. Therefore, perception of taxpayer's fairness be positively influenced by both gender and trust. 
The relationship between perceptions of fairness and intentions of compliance is found to be positively correlated in this study. This is similar to the results from Gilligan \& Richardson (2005), Kirchler et al. (2006), Saad (2014), Gberegbe (2015), and Casal et al. (2016). They found a positive relationship between perception of fairness and compliance intentions with significant influence that makes perception of fairness as one important factor in determining compliance intentions. As Kirchler said, this can happen if the authorities treat them equally, responsibly, and respectfully, it leads to the increase of taxpayers' fairness perception and so the increase in compliance intentions. Thus, the compliance intentions of taxpayers be positively impacted by perception of fairness.

Most notably, the mediating role of perception of fairness in the relationship between gender and compliance intentions, also trust in government and compliance intentions be successfully examined in this study. Agree with Hubbell \& Chory-Assad (2005), DeConinck (2010), and Holtz (2013), who proved that trust and perception of fairness have a close relationship with each other, in which the perception of fairness derives from the trust and the perception of fairness affects the intentions of tax compliance. On the other hand, Niderle \& Vesterlund (2007) shared that overestimation and overconfidence of male lead to lower perception of fairness and Cadsby et al. (2006) reported that female has higher obedience level to authority than male resulting in the more compliance. Finally, perception of fairness performs its role well in mediating the affection of gender and trust in government on tax compliance intentions.

\section{CONCLUSION}

Globally, the dependency on the enforcement of persons with income tax law on a voluntary basis is felt by many governments. Nonetheless, revenue lost due to the avoidance of individual taxpayers is considerable. Such governments are constantly search for ways to boost communication with taxpayers regarding their compliance. Government could actually increase the penalties and lift the audit rates in order to improve tax compliance, but the implementation of these compliance programs is costly. Therefore, knowing the many different factors affecting tax compliance may help policymakers create alternative compliance strategies.

Before, compliance with individual taxes was based primarily on economic factors. While these studies found economic factors to be helpful in explaining the behavior of individual tax compliance, a suggestion arose that decisions on tax compliance are not affected by economic factors only. A psychological study suggests that psychological issues in society and individuals significantly impact the decisions. This study documents the findings of a survey undertaken by 150 Indonesian taxpayers to analyze the effect of requirements on compliance with individual taxpayers.

We have looked at the impact of trust in government and perception of tax fairness on compliance intentions. A correlation between trust in government and perception of fairness is found then followed by a relationship to tax compliance intentions. In this study, as a result of trust, we use Holtz's (2013) trust model into the literature on fairness and tax compliance. That is, an entity's acts are considered fair or unjust depending on how much it is trusted.

In addition, we examine the effects of gender, namely male and female, on perceptions of fairness and continue to the intentions of tax compliance. In this study, perceptions of fairness are affected by gender and tax compliance intentions are influenced by perceptions of fairness, so perceptions of fairness plays as mediator between gender and tax compliance intentions.

Due to limited time and several restrictions, this study certainly has some limitations as follows. First, this study was only conducted in the Jabodetabek area so the results could not 
generalize the samples in other areas. Future research can conduct research in other areas in order to see if there are differences in results.

Second, this study only examined gender, trust in government, and perception of fairness as factors that determine tax compliance. The next researcher could then examines other factors as independent variables, such as tax amnesty, sanctions, and service (Serim et al., 2014), or other factors that have a significant effect on tax compliance.

Third, this study only used primary data as a data collection method. For further research could use secondary data or a combination of both to investigate the variables. This study's findings can provide policymakers with information on ways to improve tax compliance. For instance, the government can increase transparency, accountability, and responsiveness to increase public trust in the government which stimulates an increase in tax compliance (Beshi \& Kaur, 2019). In addition, on both male and female, it is also important to cultivate a sense of voluntarily compliance by the role of tax education (Kwok \& Yip, 2018).

\section{REFERENCES}

Alarcon, G. M., Lyons, J. B., Christensen, J. C., Klosterman, S. L., Bowers, M. A., Ryan, T. J., . . . Wynne, K. T. (2017). The effect of propensity to trust and perceptions of trustworthiness on trust behaviors in Dyads. Behavior Research Methods, 50(5), 1906-1920.

Allingham, M. G., \& Sandmo, A. (1972). Income tax evasion: A theoretical analysis. Journal of Public Economics, 1(4), 323-338.

Alm, J. (1991). A Perspective on the experimental analysis of taxpayer reporting. The Accounting Review, 66(3), 577-593.

Andreoni, J., Erard, B., \& Feinstein, J. (1998). Tax compliance. Journal of Economic Literature, 36(2), 818-860.

Anselmi, D. L., \& Law, A. L. (1998). Questions of Gender: Perspectives and Paradoxes. London: McGraw-Hill.

Azmi, A. A., \& Perumal, K. A. (2008). Tax fairness dimensions in an Asian context: The Malaysian perspective. Review of Integrative Business and Economics Research, 4(5), 11-19.

Barratt, M. J., Ferris, J. A., \& Lenton, S. (2014). Hidden populations, online purposive sampling, and external validity. Field Methods, 27(1), 3-21.

Beshi, T. D., \& Kaur, R. (2019). Public trust in local government: Explaining the role of good governance practices. Public Organization Review, 17(2), 1-14.

Blanthorne, C., \& Kaplan, S. (2008). An egocentric model of the relations among the opportunity to underreport, social norms, ethical beliefs, and underreporting behaviour. Accounting, Organizations and Society, 33(8), 684-703.

Bucciol, A., \& Piovesan, M. (2011). Luck or cheating? A field experiment on honesty with children. Journal of Economic Psychology, 32(1), 73-78.

Cadsby, C. B., Maynes, E., \& Trivedi, V. U. (2006). Tax compliance and obedience to authority at home and in the lab: A new experimental approach. Experimental Economics, 9(4), 343-359.

Casal, S., Kogler, C., Mittone, L., \& Kirchler, E. (2016). Tax compliance depends on voice of taxpayers. Journal of Economic Psychology, 56(1), 141-150.

Charness, G., \& Gneezy, U. (2012). Strong evidence for gender differences in risk taking. Journal of Economic Behavior \& Organization, 83(1), 50-58.

Chong, V. K., \& Monroe, G. S. (2013). The impact of the antecedents and consequences of job burnout on junior accountants' turnover intentions: A structural equation modelling approach. Accounting and Finance, 55(1), 105-132. 
Cohen-Charash, Y., \& Spector, P. (2001). The role of justice in organizations: A metaanalysis. Organizational Behavior and Human Decision Processes, 86(2), 278-321.

Cronson, R., \& Gneezy, U. (2009). Gender differences in preferences. Journal of Economic Literature, 47(1), 448-474.

Davis, J., Hecht, G., \& Perkins, J. (2003). Social behaviors, enforcement, and tax compliance dynamics. The Accounting Review, 78(1), 39-69.

DeConinck, J. (2010). The effect of organizational justice, perceived organizational support, and perceived supervisor support on marketing employees' level of trust. Journal of Business Research, 63(12), 1349-1355.

DPR RI, K. (2019). Pendapatan negara didominasi perpajakan. Retrieved from Dewan Perwakilan Rakyat Republik Indonesia: http://www.dpr.go.id/berita/detail/id/24532/t/Pendapatan+Negara+Didominasi+Perpaj akan

Eckel, C. C., \& Grossman, P. J. (2008). Men, women and risk aversion: Experimental evidence. Handbook of Experimental Economics Results, 1(7), 1061-1073.

Etzioni, A. (1986). Tax evasion and perceptions of tax fairness: A research note. Journal of Applied Behavioral Science, 22(2), 177-185.

Feicht, R., Grimm, V., Rau, H., \& Stephan, G. (2017). On the impact of quotas and decision rules in collective bargaining. European Economic Review, 100(4), 175-192.

Feld, L. P., \& Frey, B. S. (2002). Trust breeds trust: How taxpayers are treated. Economics of Governance, 3(2), 87-99.

Feld, L. P., \& Frey, B. S. (2007). FTax compliance as the result of a psychological tax contract: The role of incentives and responsive regulation. Law Policy, 29(1), 102120.

Filippin, A., \& Crosetto, P. (2016). A reconsideration of gender differences in risk attitudes. Management Science, 62(11), 3138-3160.

Fochmann, M., \& Kroll, E. B. (2016). The effects of rewards on tax compliance decisions. Journal of Economic Psychology, 52(1), 38-55.

Folger, R., \& Cropanzano, R. (2001). Fairness theory: Justice as accountability. Advances in Organizational Justice, 1(1), 1-55.

Forest, A., \& Sheffrin, S. M. (2002). Complexity and compliance: An empirical investigation. National Tax Journal, 55(1), 75-88.

Fransson, N., \& Biel, A. (2000). Gender differences in pay expectation among different occupational groups. Goteborg Psychological Reports, 30(7), 1-12.

Frey, B. S., \& Torgler, B. (2007). Tax morale and conditional cooperation. Journal of Comparative Economics, 35(1), 136-159.

Gberegbe, F. B., Idornigie, G. A., \& Davies, L. O. (2015). Perception of tax fairness and personal income tax compliance in Ken Saro-Wiwa Polytechnic. Journal of Economics and Finance, 6(6), 1-11.

Gilligan, G., \& Richardson, G. (2005). Gilligan, perceptions of tax fairness and tax compliance in Australia and Hongkong: A preliminary study. Journal of Financial Crime, 12(4), 331-343.

Gobena, L. B., \& Van Dijke, M. (2016). Power, justice, and trust: A moderated mediation analysis of tax compliance among Ethiopian business owners. Journal of Economic Psychology, 52(1), 24-37.

Gooderman, P., Nordhaug, O., Ringdal, K., \& Birkelund, E. (2004). Job values among future business leaders: The impact of gender and social background. Scandinavian Journal of Management, 20(3), 277-295. 
Guzel, S. A., Ozer, G., \& Ozcan, M. (2019). The effect of the variables of tax justice perception and trust in government on tax compliance: The case of Turkey. Journal of Behavioral and Experimental Economics, 78, 80-86.

Hair, J. F., Black, W. C., Babin, B. J., \& Anderson, R. E. (2010). Multivariate data analysis (7th Edition). New York: Pearson.

Hair, J., Hult, T., Ringle, C., \& Sarstedt, M. (2013). A primer on partial least squares structural equation modelling (PLS-SEM). Los Angeles: Sage.

Herda, D., \& Lavelle, J. (2011). The effects of organizational fairness and commitment on the extent of benefits big four alumni provide their former firm. Accounting, Organizations, and Society, 36(3), 156-166.

Hetherington, M. J. (2005). Why trust matters: Declining political trust and the demise of American liberalism. Princeton, New Jersey: Princeton University Press.

Holtz, B. (2013). Trust primacy: A model of the reciprocal relations between trust and perceived justice. Journal of Management, 39(7), 1891-1923.

Hubbell, A., \& Chory-Assad, R. (2005). Motivating factors: Perceptions of justice and their relationship with managerial and organizational trust. Communication Studies, 56(1), 47-70.

James, S., \& Alley, C. (2002). Tax compliance, self assessment and tax administration. Journal of Financial and Management in Public Services, 2, 27-42.

James, S., \& Alley, C. (2004). Tax compliance, self assessment and tax administration. Journal of Finance and Management in Public Service, 2(2), 27-42.

Jimenez, P., \& Iyer, G. S. (2016). Tax compliance in a social setting: The influence of social norms, trust in government, and perceived fairness on taxpayer compliance. Advances in Accounting, 34(1), 17-26.

Kahneman, D. (1995). Varieties of counterfactual thinking. What Might Have Been: The Social Psychology of Counterfactual Thinking, 1(1), 375-396.

Kemenkeu RI. (2018). APBN kita: Kinerja dan fakta. Jakarta: Kementrian Keuangan Repbulik Indonesia.

Kirchler, E., Hoelzl, E., \& Wahl, I. (2008). Enforced versus voluntary tax compliance: The slippery slope framework. Journal of Economic Psychology, 29(2), 210-225.

Kirchler, E., Niemirowski, A., \& Wearing, A. (2006). Shared subjective views, intent to cooperate and tax compliance: Similarities between Australian taxpayers and tax officers. Journal of Economic Psychology, 27(4), 502-517.

Kogler, C., Batrancea, L., Nichita, A., Pantya, J., Belianin, A., \& Kirchler, E. (2013). Trust and power as determinants of tax compliance: Testing the assumptions of the slippery slope framework in Austria, Hungary, Romania and Russia. Journal of Economics Psychology, 34, 169-180.

Kornhauser, M. (2007). A tax morale approach to compliance: Recommendations for the IRS. Florida Tax Review, 8(6), 340-599.

Kwok, B. Y., \& Yip, R. W. (2018). Is tax education good or evil for boosting tax compliance? Evidence from Hong Kong. Asian Economic Journal, 32(4), 359-386.

McCaffrey, E., \& Baron, J. (2004). Framing and taxation: Evaluation of tax policies involving household composition. Journal of Economic Psychology, 25(6), 679-705.

Misu, B. (2011). A Review of Factors for Tax Compliance. Dunarea de Jos University of Galati, 17(1), 69-76.

Muehlbacher, S., Kirchler, E., \& Schwarzenberger, H. (2011). Voluntary versus enforced tax compliance: Empirical evidence for the slippery slope framework. Journal of Law Economics, 32(1), 89-97.

Murphy, K. (2004). The role of trust in nurturing compliance: A study of accused tax avoiders. Law and Human Behavior, 28(2), 187-209. 
Nakayachi, K., \& Cvetkovich, G. (2010). Public trust in government concerning tobacco control in Japan. Risk Analysis, 30(1), 143-152.

Niderle, M., \& Vesterlund, L. (2007). Do women shy away from competition? Do men compete too much? Quarterly Journal of Economics, 122(3), 1067-1101.

Reuben, E., \& Winden, F. V. (2010). Fairness perceptions and prosocial emotions in the power to take. Journal of Economic Psychology, 31(6), 908-922.

Richardson, G. (2005). An exploratory cross-cultural study of tax fairness perceptions and tax compliance behavior in Australia and Hongkong. International Tax Journal, 31(1), 11-67.

Richardson, G. (2008). The relationship between culture and tax evasion across countries. Journal of International Accounting, Auditing and Taxation, 17(2), 67-78.

Rousseau, D. M., Sitkin, S. B., Burt, R. S., \& Camerer, C. (1998). Not so different after all: A cross-discipline view of trust. Journal of Mangement, 39(7), 1891-1923.

Rudolph, T. J. (2009). Political trust, ideology, and public support for tax cuts. Public Opinion Quarterly, 73(1), 144-158.

Saad, N. (2009). Fairness perceptions and compliance behavior: The case of salaried taxpayers in Malaysia after implementation of the self-assessment system. Journal Tax Research, 8(1), 32-63.

Saad, N. (2014). Tax knowledge, tax complexity and tax compliance: Taxpayerse view. Procedia-Social and Behavioural Sciences, 109, 1069-1075.

Sanders, D., Reckers, P., \& Lyer, G. (2008). Influence of accountability and penalty awareness on tax compliance. Journal of the American Taxation Association, 30(2), $1-20$.

Schneck, S. (2013). My wage is unfair! just a feeling or comparison with peers? Review of Behavioral Economics, 1(3), 245-273.

Serim, N., Inam, B., \& Murat, D. (2014). Factors affecting tax compliance of taxpayers: the role of tax officer the case of Istanbul and Canakkale. Business and Economics Research, 5(2), 19-31.

Spicer, M. W., \& Becker, L. A. (1980). Fiscal inequity and tax evasion: An experimental approach. National Tax Journal, 33(2), 171-175.

Torgler, B. (2003). Tax morale, rule-governed behaviour and trust. Constitutional Political Economy, 14(2), 119-140.

Torgler, B. (2007). Tax compliance and tax morale: A theoretical and empirical analysis. Northampton, MA: Edward Elgar Publishing, Inc.

Torgler, B., \& Schneider, F. (2005). Attitudes toward paying taxes in Austria: An empirical analysis. Empirica, 32(2), 231-250.

Wenzel, M. (2004). An analysis of norm processes in tax compliance. Journal of Economic Psychology, 25(2), 213-228.

Wenzel, M., \& Thielmann, I. (2006). Why we punish in the name of justice: Just desert versus value restoration and the role of social identity. Social Justice Research, 19(4), 450-470. 